5. Chrystal. G. in Bathymetrical Survey of the Scottish Fresh water Lochs Vol. 1, 29-90 (Challenger Ofice, Edin burgh, 1910).

6. Smith, 1. R. Freshwater Biol 9, 119-145 (1979).

7. Wilson, B. W. Adv. Hydrosci. 8, 1-94 (1972)

8. George, D. G. Freshwat Biol. 11, 37-60 (1981).

9. Duck, R. W. thesis, Univ. Dundee (1982).

10. Mortimer, C. H. Phil. Trans. R. Soc. B236, 355-404 (1952).

\section{Control of fertility in red deer}

LOUDON ET AL. ${ }^{1}$ have recently invoked a suckling-mediated mechanism for the control of fertility in red deer hinds. We suggest that their emphasis on the role of prolactin is not justified by their data and that other explanations are equally likely.

Although plasma prolactin concentrations are positively associated with the frequency of suckling ${ }^{2}$, the authors fail to show a significantly higher plasma prolactin level after 80 days, between groups of hinds on low versus high planes of nutrition, despite the persistence of high suckling frequencies in the former. There is a minimum lag of some $\mathbf{3 0}$ days separating this latest detection of a difference in plasma prolactin levels between the groups and the earliest possible conception on day 110 - when the stag was introduced. It is questionable as to whether there would be an ovulation-inhibiting effect of increased plasma prolactin levels this far in advance of ovulation, even if, as has been suggested ${ }^{3}$, such an effect were to operate on the follicular stage of the 18.3 day oestrous cycle ${ }^{4}$. This is assuming that prolactin has a causal influence on oestrus cycle activity which itself remains in doubt ${ }^{5}$.

Loudon et al. do not attempt to separate from the suckling data the confounding effect of differences in mean body weight between the two groups. It is well established that body weight not only influences fertility rates but may also affect the onset of oestrus in mammais ${ }^{6}$. In farmed red deer small hinds calve later than heavy hinds: a $1 \mathrm{~kg}$ increase advancing calving by between 0.3 and 1.0 days (ref. 7 and A.S.I. Loudon, personal communication). Furthermore, in the wild the average nonlactating hind calves approximately 2 days earlier for every $1 \mathrm{~kg}$ increase in mean autumn body weight ${ }^{8}$. Therefore a $4.1 \mathrm{~kg}$ difference in mean body weights between the two groups could explain the 6.5 day difference in return to oestrus and could be tested with their data. However, even if this is plausible and weight for weight hinds on a low nutritional plane return to oestrus later, this may be for reasons other than lactational control. For example, it is well known that in sheep, which cease lactation many weeks before the rut, body condition interacts with the plane of nutrition immediately before breeding ${ }^{9}$. At a given weight individuals that are rapidly improving in condition, as might be expected in the group of hinds on permanent grass pasture, show earlier ovulation and higher ovulation rates.

In summary, Loudon et al. concur with at least one other study in failing to show any influence of the plane of nutrition on plasma prolactin levels during or immediately before the onset of the reproductive period $^{10}$. As a consequence, they have little reason to invoke elevated levels of prolactin as a mechanism delaying conception in poorly nourished hinds. Finally, by not controlling in any way for maternal body weight and/or condition, the major confounding variable is not eliminated nor its contribution to the observed effect even brought into question.

S. D. ALBON

G. R. IASON

Large Animal Research Group,

Department of Zoology,

University of Cambridge,

Downing Street,

Cambridge CB2 3EJ, UK

1. Loudon, A. S. 1., McNeilly, A. S. \& Milne, J. A. Nature 302, 145-147 (1983).

2. McNeilly, A. S. Br. med. Bull. 35, 151-154 (1979)

3. McNeilly, A. S., Glasier, A.. Jonassen. J. \& Howie, P. W. J. Reprod. Fer. 65, 559-569 (1982).

4. Guinness. F. E., Lincoln, G. A. \& Short. R. V. J. Reprod. Fert. 27, 427-438 (1971).

5. Webster, G. M. \& Haresign, W. J. Reprod. Fert. 67, 465471 (1983)

6. Ssdleir. R. M. F. S. The Ecology of Reproduction in Wild and Domestic Mammals (Methuen, London. 1969).

7. Hamilton, W. J. \& Blaxter, K. L. J. agric. Sci, Camb. 95 261-273 (1980)

8. Mitchell, B. \& Lincoln. G. A. J. Zool. 171, 141-152 (1973) Gunn, R. G. \& Daney, J. N. J. agric. Sci., Camb. 85, 465-470 (1975)

10. Rhind, S. M. Robinson, J. J., Chesworth, J. M. \& Crolts, R. M. J. J. Reprod. Fen. 58, 145-152 (1980)

LOUDON ET AL. REPLY-In our paper we drew attention to the influence of pasture type on the milk yield, suckling patterns and fertility of red deer hinds. We were alerted to the physiological implications of the differences in suckling pattern when we considered our data on prolactin. These data, in common with a number of other studies, showed that prolactin levels were correlated with suckling frequency. At no point in our paper did we suggest that prolactin per se was ultimately involved in the regulation of fertility in red deer. Indeed we would suggest that in seasonally breeding mammals such as deer and sheep prolactin may have little influence on fertility. Thus, sheep treated with bromocriptine to block the normal high levels of prolactin in mid-summer resumed fertility at an identical time to untreated control sheep $p^{1.2}$. Thus although prolactin may have an important function in regulating fertility in some mammals including humans, we agree with Albon and lason that there is little evidence that it may be directly important in the case of red deer.

We know of only one study that attempted to control female weight, food intake, milk yield and offspring growth rate while manipulating suckling frequency. In this study, ewes compelled to suckle their offspring twice a day resumed oestrous activity at an earlier date than those permitted to suckle five times a day ${ }^{3}$. We acknowledge that there is clear evidence that the body condition of non-lactating sheep prior to mating has an effect on their fertility but suggest that in the cases of wild mammals, including red deer, which, unlike sheep, frequently suckle their offspring through the mating period, the pattern of suckling activity may have a profound effect on their subsequent fertility. Body weight per se, like prolactin, simply correlates with differences in return to oestrus in red deer. We are unable to attribute differences in body weight between the two groups of hinds to differences in body condition or differences in gut fill associated with the complex effects of grazing different grass pastures.

\section{A. S. I. LOUDON}

Institute of Zoology,

Regents Park,

London NW1 4RY, UK

A. S. MCNEILLY

MRC Reproductive Biology Unit,

Centre for Reproductive Biology,

37 Chalmers Street,

Edinburgh EH3 9EW, UK

J. A. MILNE

Hill Farming Research Organisation,

Bush Estate, Penicuik,

Midlothian EH26 OPY, UK

1. Fitzgerald, B. P. \& Cunningham, F. J. J. Reprod. Fen. 61 , 141-148 (1981)

2. Land, R. B. Carr, W. R. McNeilly, A. S. \& Preece, R. D. J. Reprod. Fert. 59, 73-78 (1980).

3. Dingwall, W. S., Robinson, J. S. \& Atkinson, T. Anim Prod. 34, 370 (1982)

\section{Matters Arising}

Matters Arising is meant as a vehicle for comment and discussion about papers that appear in Nature. The originator of a Matters Arising contribution should initially send his manuscript to the author of the original paper and both parties should, wherever possible, agree on what is to be submitted. Neither contribution nor reply (if one is necessary) should be longer than 500 words and the briefest of replies, to the effect that a point is taken, should be considered. 